\title{
Histopathological alterations in testicular tissue of male rats exposed to arsenic
}

\author{
R eema Pachnanda* and Shiv Pal Singh \\ PG Department of Zoology, D.B.S. (P.G.) College, Dehradun, 248001 (Uttarakhand), INDIA \\ *Corresponding author. E-mail: reema_pachnanda@rediffmail.com \\ Received:April 3, 2012; Revised received:J uly 15, 2012; Accepted: 0 ctober 3, 2012
}

\begin{abstract}
The present study was designed to investigate the adverse effect of arsenic on testicular tissue of Swiss albino male rats. Sodium arsenite was administered to adult male rats by gavage at the doses 1,2 and $3 \mathrm{mg} / \mathrm{kg}$ body weight for 30 days. After the treatment, the testis were processed for histopathological observations. Sodium arsenite caused remarkable reduction in testicular weight $(P<0.05)$, while the body weight of experimental animals were reduced but not significantly $(\mathrm{P}<0.05)$. Histological evaluation revealed dose-dependent, gradual destruction in histoarchitecture of testicular tissue. Sodium arsenite exposure caused complete arrest of spermatogenesis with disfigured seminiferous tubules in the testes. The lumens of the tubules were devoid of spermatids and were in places filled with cellular debris. The germinal epithelium was distorted. At places interstitial odema was also evident. Sertoli and Leydig cells were damaged. Along with structural alterations, fertility rate in experimental animals was significantly decreased at higher doses i.e. 2 and $3 \mathrm{mg} / \mathrm{kg}$, as $100 \%$ infertility was observed. After withdrawal of the treatment over a period of 30 days, recovery was observed in low dose groups as few female rats became pregnant. The study concluded that exposure of arsenic causes testicular toxicity in male albino rat.
\end{abstract}

Keywords: Arsenic, Fertility test, Histopathology, Reversibility test, Swiss albino rats, Testicular tissue

\section{INTRODUCTION}

Arsenic is an important environmental toxicant and carcinogen (ATSDR, 1993 and IARC, 1980, 2004).It is present ubiquitously in the environment by both natural and anthropogenic activities. Mining, smelting of nonferrous metals, burning of fossil fuels, use of arsenic in pesticides, wood preservatives, paints etc. are the major sources that contributes to the contamination of arsenic in the environment. Chronic exposure to arsenic through drinking water is a major health concern throughout the world (Chatterjee et al., 1995; NRC, 1999). Drinking arsenic- rich water over a long period results in various health effects including skin problems, cancer of bladder, kidney and lung, diabetes, cardiovascular diseases, neurological and cognitive defects, and reproductive disorders (Tchounwou et al., 2003).

Arsenic is known reproductive toxicant, adversely affecting reproductive system. Several studies on the toxic effect of arsenic on reproductive system of various animal models have been carried out and reported that inorganic arsenic through drinking water induced male and female reproductive and developmental toxicities (Golub et al., 1998; Wang et al., 2006). Gonadal effects of arsenic were first evaluated in mice, then in fishes (Shukla and Pandey, 1984). Previous studies suggested that this toxicant has a suppressive influence on spermatogenesis and androgenesis in male reproductive system (Sarkar et al., 2003). In laboratory animals, arsenic causes several disturbances to the male reproductive function which ISSN : 0974-9411 (Print), 2231-5209 (Online) All Rights Reserved ๑ Applied and Natural Science Foundation www.ansfoundation.org includes inhibition of spermatogenesis, obstruction to steroidogenesis, impairment of accessory sex gland function, disorders in the sperm motility, and reduction in sperm number and genital organ weight (Pant et al., 2004). Moreover arsenic in drinking water is also associated with oxidative stress and genotoxicity in testicular tissue of mice (Tabacova et al., 1992; Liu et al., 2001; Jana et al., 2006; Mehranjani and Hemadi, 2007 and Sarkar et al., 2008). Thus, on behalf of above facts, the present study was undertaken to study the reproductive toxic effect of arsenic on testicular tissue of male albino rats.

\section{MATERIALS AND METHODS}

Experimental animals: Healthy adult, Swiss albino male rats, Rattus rattus norvegicus, weighing between 170 $200 \mathrm{~g}$, were used for the experiments. They were housed in cleaned room under normal natural conditions of room temperature and photoperiod which was around 12-14 hrs and were acclimatized for 7 days to the laboratory conditions, prior to commencement of the experiment. All the rats were maintained on balanced laboratory feed and drinking water ad libitum. The experimental protocol of the present study on male albino rats was approved by the Institutional Animal Ethics Committee (IAEC). The Principles of Laboratory Animal Care (NIH Publication No 85-23, revised in 1985) as well as specific Indian Laws of Animal Protection (ILAP) were followed throughout the experimental schedule. 
Chemical and its treatment: Sodium arsenite, an arsenical compound, was purchased from Loba Chemie Pvt. Ltd., Mumbai, India. The chemical used was of highest purity commercially available. Sodium arsenite was dissolved in distilled water to make desired concentrations (1, 2 and $3 \mathrm{mg} / \mathrm{kg}$ body weight) and was given by gavage. Forty adult male albino rats were randomly divided into four groups (10 rats /group).Group I served as control while Group II, III and IV treated as experimental groups and administered with sodium arsenite orally at the dosages of $1 \mathrm{mg}, 2 \mathrm{mg}$ and $3 \mathrm{mg} / \mathrm{kg}$ body weight respectively over a period of 30 days. Equal volume of distilled water was administered to control rats following the same schedule. After 30 days of experiment, five animals from each group were used for histopathological study while remaining animals in each group were kept without treatment for another 30 days which were used for fertility performance and reversibility test.

\section{Parameters studied:}

Body and or gan weight: Initial and final body weight of both control and treated animals were recorded prior to and after the completion of the experiment. After 30 days of treatment, the experimental animals were dissected after 24 hours of the last dose under light ether anesthesia .The testis was removed, freed from adherent tissue and blood and wet weight was determined.

$\mathrm{H}$ istopathological study: The reproductive male organ i.e. Testis were fixed in Bouin's fixative, embedded in paraffin wax by routine method and thin sections were cut at 6um thickness and stained with hematoxylin- eosin for microscopic evaluation

Fertility performance and reversibility study: Immediately after 30 days of exposure, fertility test was carried out. Male rats were cohabited with untreated, adult female rats of proven fertility. Vaginal smear samples were collected and examined for the presence of sperms. Those females which had plenty of spermatozoa in the vaginal smear and resulted in pregnancy were scored as fertile matings. The day on which the vaginal smear showed the presence of spermatozoa, was considered day first of pregnancy. The mated females were laparotomised on day tenth of pregnancy and the implantation sites in uterus were observed. Those females which failed to show implantation sites were scored as infertile matings. For reversibility study, the male rats which were used for fertility performance test, mated again with proven fertile female rats after 30 days of discontinuation of arsenite treatment.

Statistical analysis: The significance of difference of weights between treated and control rats was assessed by students ' $\mathrm{t}$ ' test, taking $\mathrm{P}<0.05$ as significance.

\section{RESULTS}

Body and genital organs weight: The body weights of treated animals were reduced at all doses of Sodium arsenite but not significantly as compare to control rats. However, a significant reduction in the testicular weight was observed at all dose levels after 30 days experiment. The body and genital organ weight of both treated and control groups are presented in Table 1.

Histopathological examination:

Control: The histology of testes of control rats showed a normal histoarchitecture. The tunica propria was well organized and seminiferous tubules with regular stages of spermatogenesis from spermatogonia to spermatozoa. The Leydig's cells were present in the intersitium. The vascularity of the organ was normal (Fig. 1).

Treated: The effect of Sodium arsenite on male reproductive organ i.e. testes was prominent at each successive dose level i.e. 1,2 and $3 \mathrm{mg} / \mathrm{kg}$ body weight. Administration of $1 \mathrm{mg} / \mathrm{kg}$ dose of Sodium arsenite for 30 days severely affected the histology of testis. The seminiferous tubules were shrunken with defective spermatogenesis and consists only a few layers of germ cells. The spermatogonia and spermatocytes displayed various changes in their organization. Many spermatocyte nuclei were swollen and a few were atrophied. Sloughing of dead germ cells occurred into the lumen of the tubule. The dissolution of the tubule membrane and leakage of germ cells into the interstitial space was evident at certain places. Leydig's cells were not clearly visible. The vascularity was also affected (Fig. 2).

The degenerative changes in the testicular element were further enhanced with the administration of $2 \mathrm{mg} / \mathrm{kg}$ dose of Sodium arsenite in comparison to the previous dose.

Table 1. Effect of sodium arsenite on body weight (gm) and genital organ weight (mg) in male albino rats administered for 30 days at different doses $(\mathrm{mg} / \mathrm{kg}) .5$ rats in each group. Values are Mean \pm S.E.

\begin{tabular}{lcccc}
\hline \multirow{2}{*}{ Name of treatment } & $\begin{array}{c}\text { Doses } \\
(\mathrm{mg} / \mathrm{kg})\end{array}$ & \multicolumn{2}{c}{ Body weight $(\mathrm{gm})$} & Organ weight $(\mathrm{mg})$ \\
\cline { 2 - 4 } Control & Vehicle & Tnitial & Final & \\
& (Distilled water) & $171.0 \pm 1.10$ & $178.8 \pm 0.90$ & $865.2 \pm 0.91$ \\
\multirow{2}{*}{ Sodium arsenite } & 1.0 & $167.0 \pm 0.62$ & $165.2 \pm 0.40$ & $674.8 \pm 0.53^{*}$ \\
& 2.0 & $170.0 \pm 2.67$ & $167.0 \pm 2.10$ & $560.0 \pm 1.90^{*}$ \\
& 3.0 & $172.4 \pm 1.80$ & $161.0 \pm 1.73$ & $400.2 \pm 0.83^{*}$ \\
\hline
\end{tabular}

$* \mathrm{P}<0.05$ 
Table 2. Effect of different doses of sodium srsenite on the fertility of male albino rats after 30 days of the treatment.

\begin{tabular}{lccccc}
\hline & \multicolumn{2}{c}{ (F ertility performance test) } \\
\hline $\begin{array}{l}\text { Name of the } \\
\text { treatment }\end{array}$ & $\begin{array}{c}\text { Dose } \\
(\mathrm{mg} / \mathrm{kg})\end{array}$ & $\begin{array}{c}\text { No. of tr eated } \\
\text { males }\end{array}$ & $\begin{array}{c}\text { No. of normal } \\
\text { females inseminated }\end{array}$ & $\begin{array}{c}\text { Fertile* } \\
\text { matings }\end{array}$ & $\begin{array}{c}\text { Infertile** } \\
\text { matings }\end{array}$ \\
\hline Control & $\begin{array}{c}\text { Vehicle } \\
\text { (Distilled water) }\end{array}$ & 5 & 5 & $5(100 \%)$ & $0(0 \%)$ \\
Sodium arsenite & 1.0 & 5 & 5 & $1(20 \%)$ & $4(80 \%)$ \\
& 2.0 & 5 & 5 & $0(0 \%)$ & $5(100 \%)$ \\
& 3.0 & 5 & 5 & $0 \%(100 \%)$ \\
\hline
\end{tabular}

*Resulted in pregnancy, **Do not resulted in pregnancy.

Table 3. Effect of different doses of sodium arsenite on the fertility of male albino rats after 30 days of the withdrawal of treatment.

\begin{tabular}{lccccc}
\hline Name of the treatment & $\begin{array}{c}\text { Rose } \\
(\mathrm{mg} / \mathrm{kg})\end{array}$ & $\begin{array}{c}\text { No. of } \\
\text { treated } \\
\text { males }\end{array}$ & $\begin{array}{c}\text { No. of normal } \\
\text { females } \\
\text { inseminated }\end{array}$ & $\begin{array}{c}\text { Fertile* } \\
\text { matings }\end{array}$ & $\begin{array}{c}\text { Infertile** } \\
\text { matings }\end{array}$ \\
\hline Control & $\begin{array}{c}\text { Vehicle } \\
\text { (Distilled water) }\end{array}$ & 5 & 5 & $5(100 \%)$ & $0(0 \%)$ \\
Sodium arsenite & 1.0 & 5 & 5 & $2(40 \%)$ & $3(60 \%)$ \\
& 2.0 & 5 & 5 & $1(20 \%)$ & $4(80 \%)$ \\
& 3.0 & 5 & 5 & $0(0 \%)$ & $5(100 \%)$ \\
\hline
\end{tabular}

*Resulted in pregnancy,** Do not resulted in pregnancy.

The seminiferous tubules showed shrinkage and had a wavy outline. The spermatogenesis occurred upto secondary spermatocytes. Only one or two layers of germ cells were evident with their swollen nuclei. The lumen of the tubule was filled with sloughed germ cells. The interstitial spaces were enlarged with no presence of Leydig's cells. Vascularity was highly reduced (Fig. 3).

The antispermatogenic effect was more pronounced following the treatment with the $3 \mathrm{mg} / \mathrm{kg}$ dose of Sodium arsenite for 30 days. The treatment produced a wide spread damage in germinal elements of testis. The seminiferous tubules were highly atrophied with marked inhibition of spermatogenesis at spermatogonial stage. The seminiferous tubules lumen contained desquamated germinal elements and oedematous fluid. Some of the tubules had only spermatogonia with empty lumen. Germinal epithelium was degenerated. The connective tissue stroma was completely lost and wide spaces between tubules were visible. The Leydig's cells were absent. Vascularity was poor (Fig. 4).

E ffect on fertility performance and rever sibility: When male rats of controlled group mated with normal female rats, all the females became: pregnant. This showed $100 \%$ fertile matings. But when sodium arsenite salt was administered to male rats for 30 days, it inhibited the fertile mating at all the dose levels. The infertile mating was $80 \%$ for the dose level of $1 \mathrm{mg} / \mathrm{kg}$ while at higher doses i.e. $2 \mathrm{mg}$ and $3 \mathrm{mg} / \mathrm{kg}, 100 \%$ inhibition of fertile mating was observed. Thus higher doses were able to induce $100 \%$ infertility in the treated male rats (Table 2). After 30 days of discontinuation or withdrawal of treatment, the fertility test was again performed to see the reversibility, if any. It was found that the fertility was restored in some of the male rats. At $1 \mathrm{mg} / \mathrm{kg}$ dose level, the $40 \%$ of rats regained fertility. At the dose level of $2 \mathrm{mg} / \mathrm{kg}$, the $20 \%$ of rats exhibited fertile matings while at the highest dose level i.e. $3 \mathrm{mg} / \mathrm{kg}$, none of the rat showed fertile matings i.e. $100 \%$ infertility. Thus, the effect appeared to be reversible (Table 3).

\section{DISCUSSION}

The toxic effects of arsenic on human health have been well documented (Pershagen, 1983; Abernathy et al., 1999; and Centeno et al., 2002). Arsenic intoxication has been associated with male reproductive toxicity in experimental animals and have the potential to produce adverse effect on their fertility (Golub et al., 1998 and Wang et al., 2006).

In the present study, arsenic produced significant alterations in the histoarchitecture of testes, which includes degeneration of seminiferous tubules, mass atrophy of the spermatogenic elements which is evidenced by absence of sperm bundle in the seminiferous tubules, atrophy of Leydig and Sertoli cells. Similar histological observations haved been made by Omura et al. (2000), Mehranjani and Hemadi (2007) and Sarkar et al. (2008) who reported the toxic effect of arsenic on the testicular tissues of male rats.

From above observations, it was obvious that alteration in the histological structure of testes was due to the deficient androgen production as suggested by Paul et al. (1953), Dorfman et al. (1963) and Nelson and Patanelli (1965) under arsenic toxicity. It is evident from the previous studies, that arsenic exposure diminishes the circulating 


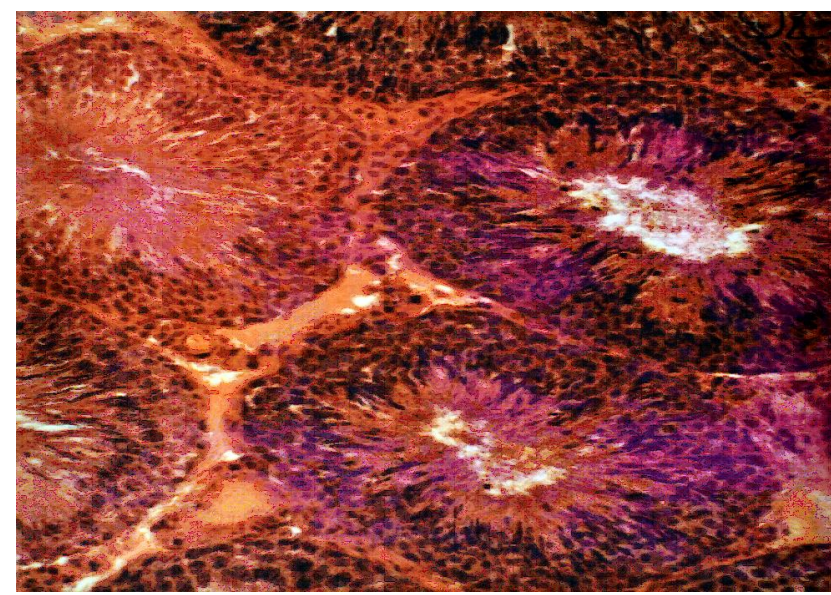

Fig. 1. T.S. of Testis of albino rat of Control group. (Full spermatogenic activity in seminiferous tubules and normal Leydig's cells in interstitium) X 250.

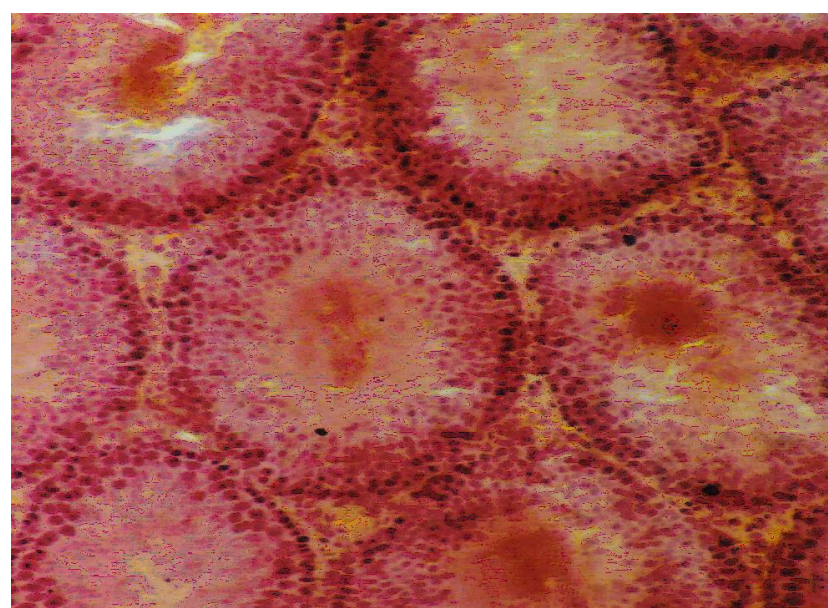

Fig. 2. T.S. of Testis of albino rat of treated group with Sodium arsenite at $1 \mathrm{mg} / \mathrm{kg}$ dose for 30 days (Spermatogenesis arrested at sper matocyte stage, dissolution of the tubular membrane and leakage of germ cells into the lumen. Leydig's cells not clearly visible) X 250;

levels of both gonadotropins i.e. FSH and LH which in turn decrease the concentration of testosterone (Sarkar et al., 2003 and Jana et al., 2006). The decline in testosterone concentration is further supported on the basis of inhibition of testicular androgenic enzymes ( 5 , $3 \beta$-HSD and $17 \beta$-HSD), regulated by the gonadotropins FSH and LH, both of which have been reported to be inhibited by following exposure to arsenic (Sarkar et al., 1991). Consequently, low serum levels of FSH and LH in arsenic-treated rats and inhibition of these testicular androgenic enzymes lead to reduction in testosterone production and thus secretion into circulation.

The diminution of testosterone level in testis can also be explained on behalf of atrophy of Leydig cells. As we known that Leydig cells play an important role in the structural and functional integrity of seminiferous tubules and synthesis of testosterone, which is one of the main component of regulation of spermatogenesis (Steinberger

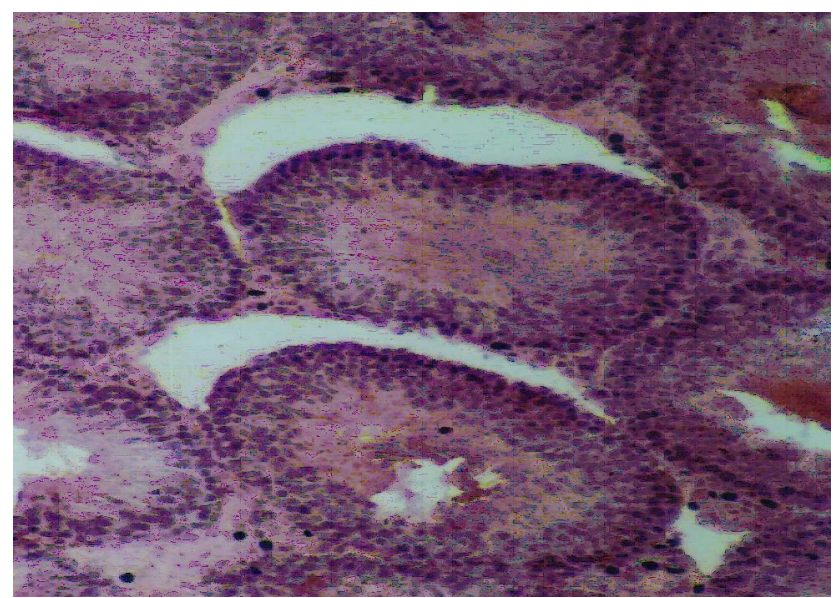

Fig. 3. T.S. of Testis of al bino rat of treated group with Sodium arsenite at $2 \mathrm{mg} / \mathrm{kg}$ dose for 30 days (Shrinkage and deshaped seminiferous tubules, degenerated cellular elements and reduced vascularity) $X 250$.

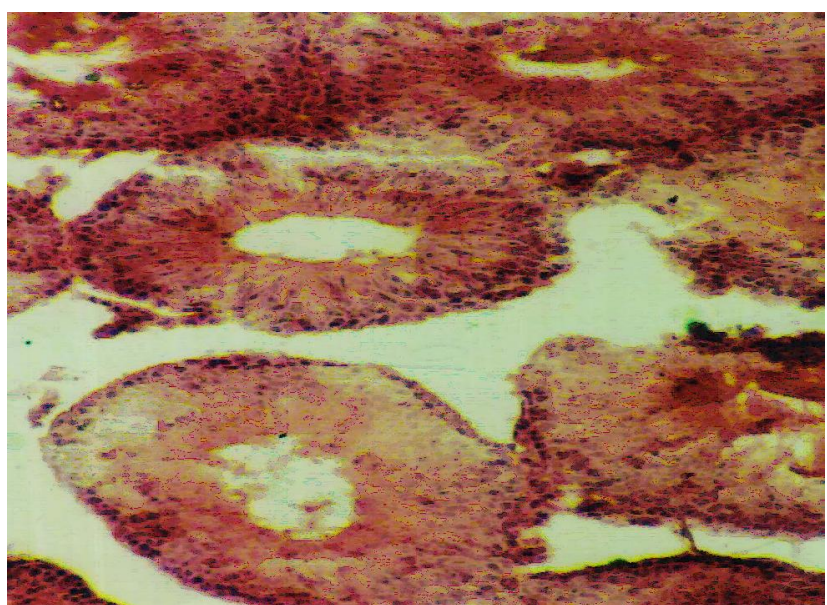

Fig. 4. T.S. of Testis of al bino rat of treated group with Sodium arsenite at $3 \mathrm{mg} / \mathrm{kg}$ dose for 30 days (The extensive destruction of germinal cells, seminiferous tubules highly atrophied, occluded with debris and degener ated spermatozoa. Leydig's cells absent and wide interstitium) X250.

and Duckett, 1965; Sharpe et al., 1990). Thus atrophy of Leydig cells results in inhibition of testosterone synthesis. Thus, the reduction in testosterone production may therefore, be held responsible for the arsenic induced changes in spermatogenesis. Similarly anti-spermatogenic effect of arsenic was also reported in fishes (Shukla and Pandey (1984). In the present study, the spermatogenic disorder has been reflected by the diminution in the number of germ cells i.e. spermatids and spermatozoa in testes, which also leads in the reduction of testicular weight, a valuable index of reproductive toxicity in male animals. This observation is in agreement with the previous findings of Pant et al. (2004).

In present study, the mating of normal females was unsuccessful with treated males. The possible explanation for sterility is antispermatogenic and antiandrogenic effect of arsenic which is evidence by cellular regression of testicular tissue and reduction in germ cell. Thus, 
administration of sodium arsenite resulted in the impairment of reproductive performance as indicated by infertile mating that persisted in $60-100 \%$ of rats even after 30 days of discontinued of treatment. No earlier report is available on the fertility performance of this toxicant, therefore, a comparison can not be made. All our observations in the present study provide conclusive evidences that arsenic causes adverse effect on testicular tissue of rats, thereby declining the fertility of animals.

\section{REFERENCES}

ATSDR (1993).Toxicological profile of Arsenic. (Agency for Toxic Substances and Disease Registry) U.S. Public Health Services, Atlanta.

Abernathy, C.O., Liu, Y.P., Longfellow, D., Aposhian, H.V., Beck, B.,Fowler, B., Goyer, R., Menzer, R., Rossman, T., Thompson, C. and Waalkes, M. (1999). Arsenic: Health effects, mechanism of actions and research issue. Environ H ealth Perspect, 107: 593- 597.

Chatterjee, A., Das, D., Mandal, B.K., Samanta, G. and Banerjee, P. (1995).The biggest arsenic calamity in the world. Analyst, 120: 643 - 650 .

Centeno, J.A., Mullick, F.G, Martine, Z.L., Page, N. P., Gibb, H. and Longfellow, D. (2002). Pathology related to chronic arsenic exposure. Environ. Health Perspect, 110 (5): 883 - 886.

Dorfman, R.I.; Forcheilli,E. and Gut, M. ( 1963). Androgen biosynthesis and related studies. RecentProg. Horm. Res., $19: 251-273$.

Golub, M.S., Macintosh, M.S. and Baumrind, N.(1998). Developmental and reproductive toxicity of inorganic arsenic: animal studies and human concerns. J Toxicol Environ Health B C rit Rev., 1: 199-241.

IARC (1980). Monographs on the evaluation of carcinogenic risk of chemicals to humans (International Agency for Research on Cancer). In: some metals and metallic compounds. Lyon: IARC Press.Vol. 23 (pp 39-141).

IARC (2004). Monographs on the evaluation of carcinogenic risk of chemicals to humans (International Agency for Research on Cancer). In: Some Drinking Water Disinfectants and Contaminants, including Arsenic. Lyon: IARC Press.Vol. 84 pp $269-477$

Jana, K., Jana, S. and Samanta, P.K. (2006). Effects of chronic exposure to sodium arsenite on hypothalamo-pituitarytesticular activities in adult rats: possible an estrogenic mode of action. Reprod Biol Endocrinol, 4 (9): 1- 13.

Liu, S.X., Athar, M., Lippai, I., Waldren, C. and Hei, T.K. ( 2001). Induction of oxyradicals by arsenic: implication for mechanism of genotoxicity. ProC Natl Acad Sci USA, 98:1643-1648

Mehranjani, M.S. and Hemadi, M. (2007). The effects of sodium arsenite on the testis structure and sex - hormones in vasectomised rats. Iranian J ournal of Reproductive Medicine, 5 (3): 127 - 133.

Nelson, W.O. and Patanelli, D.J. (1965). Chemical control of spermatogenesis. In: Agents Affecting Fertility. (Eds. Austin,
C.R. and Perry, J.S.), Little Brown, Boston. Mass. U.S.A. 78 NIH (1985): Guide for the care and use of laboratory animals published by National institute of Health Publication USA, NIH 85-23.

NRC (National Research Council). (1999). Arsenic in the drinking water. Washington, DC: National Academy Press. pp. 1 - 310 .

Omura, M., Yamazaki, K., Tanaka, A., Hirata, M., Makita, Y. and Inoue, N. (2000). Changes in the testicular damage caused by Indium Arsenide and Indium Phosphide in hamesters during two years after intratracheal instillations. J. Occup Health, 42: 196-204.

Pershagen, G. (1983). The epidemiology of human arsenic exposure. In : Biological and Environmental effects of arsenic, B.A Flower, (Ed), Elsevier, Amsterdam. Pp 193 - 233.

Pant, N., Murthy, R.C. and Srivastava, S.P. (2004). Male reproductive toxicity of sodium arsenite in mice. Hum Exp Toxicol , 23(8) : $399-403$.

Paul, H.E., Paul, M.P., Kopko, F., Bender, R.C. and Everett, G. (1953). Carbohydrate metabolism- Studies on the testis of rat for certain nitrofurans. Endocrinology, 53 : 585-588.

Sarkar, M., Biswas, N.M. and Ghosh, D. (1991). Effect of sodium arsenite on testicular 5, 3 $\beta$-HSD and 17 $\beta$-HSD activies in albino rats : Dose and duration dependent responses. Med Sci Res, 19: $789-790$.

Sarkar, M., Chowdhury, R.G., Chattopadhayay A. and Biswas, N.M. (2003). Effect of sodium arsenite on spermatogenesis, plasma gonadotrophins and testosterone in rats. AsianJ Androl, 5: $27-31$

Sarkar, S., Hazra, J., Upadhyay, S.N., Singh, R.K. and Chowdhury, A.R. (2008). Arsenic induced toxicity on testicular tissue of mice. Indian J. Physiol Pharmacol, 52(1): $84-90$.

Sharpe, R.M., Maddocks, S., Kerr, J.B. (1990). Cell-cell interactions in the control of spermatogenesis as studied using Leydig cell destruction and testosterone replacement. American J ournal of Anatomy, 188: 3-20.

Steinberger, E. and Duckett, G.E. (1965). Effect of estrogen and testosterone in the initiation and maintenance of spermatogenesis in the rats. Endocrinology, 76: 1184 - 1189.

Shukla, J.P. and Pandey, K. (1984). Impaired spermatogenesis in arsenic treated freshwater fish, Colisa fasciatus.(Bl. and Sch.). Toxicology Letters, 21(2): $191-195$.

Tabacova, S., Hunter, E.S. and Balabaeva, L. (1992). Potential role of oxidative damage in developmental toxicity of arsenic. In Arsenic : Exposure and Health effects, ( C.O. Abernathy, R.L. ; Calderon and W.R. Chappell, Eds) pp 135 - 144. Chapman and Hall, London.

Tchounwou, P.B., Patlolla, A.K. and Centeno, J.A.( 2003). Carcinogenic and systemic health effects associated with arsenic exposure- A critical review. Toxicol Pathol, 31(6): $575-588$.

Wang, A., Holladay, S.D., Wolf, D.C., Ahmed, S.A. and Robertson, J.L.(2006). Reproductive and developmental toxicity of arsenic in rodents: a review. International J ournal of Toxicology, 25 (5): 319-331. 